Dr. Drury's clear exposition of this historic event, and the unique character of the exhibits connected with it, aroused the greatest interest, and it was agreed that Sir Charles Sherrington's interest would be even greater. A letter was accordingly written and the following is an extract from his reply dated Novem. ber 15,1947 :

". . . Thank you for kindly writing. Yes, the story was just as you say; except that dear Ruffer's first name was Armand. Poor fellow, he was torpedoed and drowned by the Germans in the lst world war. $\mathrm{He}$ was brother-in-law to Bouchard of Paris, the leading French physician in his line.

"The story of the horse at 'the Brown' had a dramatic sequel which perhaps Dr. Drury has not heard; if he has, he will, I hope, forgive my telling it; it may interest you. Ruffer and I had been injecting the horse-our first horse-only a short time. We were badly in the dark as to the dosage to employ, and how quickly to repeat the increasing injections. We had from it a serum partly effective in guinea pigs. Then, on a Saturday evening, about 7 o'clock, came a bolt from the blue. A wire from my brother-in-law in Sussex. 'George has diphtheria. Can you come ?' George, a boy of 7 , was the only child. The house, an old Georgian house, 3 miles out of Lewes, set back in a combe under a chalk down. There was no train that night. I did not at first give thought to the horse, and, when I did, regretfully supposed it could not yet be ripe for use. However, I took a cab to find Ruffer. No telephone or taxi in those days-'93 or '94. Ruffer was dining out. I pursued him and got a word with him. He said 'By all means you can use the horse, but it is not yet ripe for trial'. Then by lantern-light at 'The Brown' I bled the horse into a 2-litre flask duly sterilized and plugged with sterile wool. I left the blood in ice for it to settle. After sterilizing smaller flasks, and pipettes and some needle-syringes I drove home, to return at midnight, and decant the serum, etc.

"By the Sunday morning train I reached Lewes. Dr. Fawssett of Lewes-he had a brother on the staff at Guy's-was waiting in a dog-cart at the station. I joined him carrying my awkward package of flasks, etc. He said nothing as I packed them in, but, when I had elimbed up beside him, he looked down and said, "You can do what you like with the boy. He will not be alive at tea time.' We drove out to the old house; a bright frosty morning. Tragedy was over the place, the servants scared and silent. The boy was very weak; breathing with difficulty; he did not seem to know me. Fawssett and I injected the serum. The syringes were small and we emptied them time and again. The Doctor left. I sat with the boy. Early in the afternoon the boy seemed to me clearly better. At 3 o'clock I sent a messenger to the Doctor to say so. Thence forward progress was uninterrupted. On Tuesday I returned to London, and sought out Ruffer. His reaction was that we must tell Lister about it. The great surgeon (not Lord Lister then) had visitors, some Continental surgeons, to dinner. 'You must tell my guests about it', he said, and insisted-so we told them in the drawing-room, at Park Crescent. The boy had a severe paralysis for a time. He grew to be $6 \mathrm{ft}$. and had a commission in the lst world war.

"If Drury has not heard of this sequel to the first horse at 'the Brown' he may like to hear it; please give him my best remembrances. . . . Thank you so much for writing. . . ."

\section{OBITUAR IES}

Prof. A. N. Whitehead, O.M., F.R.S.

ALFRED North Whitehead was born on February 15, 1861, the son of the Rev. Alfred Whitehead, at that time the headmaster of a private school in Ramsgate, and later vicar of St. Peter's, Isle of Thanet, and honorary canon of Canterbury. From Sherborne School he proceeded in 1880 to Trinity College, Cambridge, of which foundation he became a fellow in 1884 and lecturer in $\mathbf{1 8 8 5}$.

As a young man, he had a place apart among Cambridge dons by reason of his interest in the outlying and comparatively unknown branches of mathematics. In the nineteenth century, this category included non-Euclidean geometry and noncommutative algebras, such as matrices and symbolic logics; and on these subjects he published in 1898 a massive and very original volume, under the title "A Treatise on Universal Algebra, with Applications".

It is interesting to observe how Whitehead's prophetic instinct led him to take up subjects which were at the time neglected and unknown to most professional mathematicians, but which have since played a great part in the interpretation of Nature. Matrix theory first came into its kingdom in 1925, when Heisenberg, Born and Jordan showed that by its aid quantum theory could be constituted as a complete logical structure. The non-Euclidean geometry of spaces of constant curvature has found its chief application in the cosmological investigations of Eddington and others from 1930 onwards, though Euclidean space had been dethroned fifteen years earlier by Einstein's theory of general relativity. The "Universal Algebra" was acclaimed on all sides as a splendid work of learning and research, and the reputation based on it led to Whitehead's election as a fellow of the Royal Society in 1903.

Of the scholars of Trinity who sat at Whitehead's feet during the last decade of the nineteenth century, there was one who became a specially attached disciple and played a great part in his subsequent life and work. This was Bertrand Russell, who entered the College in 1890 and was elected a fellow in 1895. In 1900 he and Whitehead attended an International Philosophical Congress in Paris, at which they heard an account of the work of Giuseppe Peano, who in the years immediately preceding had invented a new ideography for use in symbolic logic. They realized that Peano's symbolism was vastly superior to anything that had been known previously, and resolved to devote themselves to its development, and in particular to try to settle by its means the vexed question of the foundations of mathematics.

The thesis which they now set out to prove was that mathematics is a part of logic; it is, as they said, the science concerned with the logical deduction of consequences from the general premises of all reasoning ; so that a separate "philosophy of mathematics' simply does not exist. This, of course, contradicts the Kantian doctrine that mathematical proofs depend on a priori forms of intuition. They soon succeeded in proving that the cardinal numbers 1,2 , $3, \ldots$ can be defined in terms of concepts which belong to pure logic, and which can be represented by Peano ideograms. From this first success they advanced to the investigations published in the three colossal volumes of "Principia Mathematica", which appeared during 1910-12 and contain altogether just under 2,000 pages. 
In 1910 Whitehead resigned the Trinity lectureship and removed to London. During 1911-14 he was on the staff of University College, and from 1914 until 1924 he held a chair of mathematics in the Imperial College of Science and Technology.

There was to have been a fourth volume of the "Principia", dealing with geometry. But as Whitehead worked in preparation for it, he found himself more and more involved in questions which really belonged to epistemology and metaphysics. During 1915-17 he published several papers of a definitely philosophical character, and these were followed by two books in which he propounded a new philosophy of the external world, "An Enquiry concerning the Principles of Natural Knowledge" in 1919, and a volume of Tarner Lectures on "The Concept of Nature" in 1920. He first cleared the ground by rejecting the conceptions of Nature which then formed the accepted starting-point of physics : namely, that space and time provide, so to speak, a stage, on which ponderable bodies, æther, and electricity maintain an unending performance. In place of this, he put forward the doctrine that the ultimate components of reality are events. For example, a university lecture is an event: obviously it includes other events, such as the professor at his rostrum and the students at their desks ; moreover, it may in its turn be regarded as a part of a larger event, such as the aggregate of all the lectures given in the same building at the same hour. This property of extending over other events is characteristic of events, and is the fundamental relation on which Whitehead's philosophy of the external world is based.

An event is never instantaneous; it always endures over a certain (though perhaps very short) duration of time : "the ultimate fact for observational knowledge", as he said, "is perception through a duration". The notions of an instant of time and a point of space are not truly primitive notions : to obtain them, he introduced what he called the method of extensive abstraction. The idea of this method is to consider a set of events each of which includes all the subsequent members of the sequence, like a nest of boxes each slightly larger than the one next inside it; if the events ultimately diminish indefinitely (or in more precise language, if no event is extended over by every event of the set) then they may be regarded as defining a limit : points of space and instants of time may be defined in this way; so that time and space are derivative concepts, they are abstractions which express relations between events.

In 1924 Whitehead resigned his chair at the Imperial College in order to accept a professorship in the Philosophical Department of Harvard University, which he occupied until his final retirement in 1937. In the session 1927-28 he returned to Britain for a time in order to deliver the Gifford Lectures in the University of Edinburgh. These, which were published in 1929 under the title "Process and Reality : an Essay in Cosmology", may be regarded as the definitive exposition of his mature philosophy, to which he gave the name 'Philosophy of Organism'. In his own words, "Speculative Philosophy is the endeavour to form a coherent, logical, necessary system of general ideas in terms of which every element of our experience can be interpreted". His point of view in this endeavour must first be made clear. He turned his back on German idealist philosophy (Kant, Fichte, Schelling, Hegel), which was concerned chiefly with mind, and had little interest in the study of Nature by the methods of mathematical and experimental science. In this sense his philosophy is, as he said, "a recurrence to pre-Kantian methods of thought". In regard to particular features, he was under obligations of one sort or another to Descartes, Leibnitz, Locke, Berkeley and Hume, and among moderns to Bradley, Bergson and Alexander; but the main roots of his doctrine were to be found in Greek philosophy, and it bore a relation to modern science which may be compared with that which Platonism bore to the Pythagorean mathematical concept of the intelligible element in Nature.

The philosophy of Whitehead is in the first place a cosmology. Now one famous philosophical cosmology has come down to us from the ancient world, namely, that set forth in the "Timæus" of Plato; and the resemblances between it and Whitehead are so striking that "Process and Reality" may be described, in a first rough approximation, as the "Timæus" brought up to date. The fundamental idea in both is the gradual evolution of order out of a primeval chaos, by a process of divine achievement. The demiourgos of the "Timæus" corresponds to Whitehead's God, and the Platonic 'Ideas' or 'Forms' correspond to Whitehead's 'eternal objects', which have a potentiality of 'ingression' into the becoming of actual entities, just as the 'Forms' have participation (methexis) in visible things. The primitive plastic substratum in which copies of the 'Forms' are made (chora) corresponds to Whitehead's concept of 'creativity'.

"Process and Reality" is not an easy book to read, chiefly because of the multitude of new words, and new senses of old words, with which it teems. Only time can show how many of these will be retained as a permanent enrichment of the philosophical vocabulary.

Whitehead died at Cambridge, Mass., on December $30,1947$. EDMUND T. WHITTAKER

ON November 12,1947 , it came my way to spend, alone, a couple of hours in the evening with the late Prof. Whitehead, and Mrs. Whitehead, in their apartment within a stone's throw of the centre of Harvard. It seems likely, therefore, that I was the last person from Britain to see the great man before he died.

We talked of Trinity ("Such a good place", he whispered) and its 'characters', of whom he spoke affectionately, coupled with an occasional sly dig, as entrancing as it was kindly. He was devoted to the country of his adoption : a remark stands out in my memory-"The Americans have a streak of tenderness, yes, how valuable that is these days". Many people have used gracious words about our transAtlantic cousins, but it was left to him to state, quite simply and naturally, their noblest trait, and the one holding out hope for the world.

In appearance, Whitehead had become almost 'other-worldly' (something which others besides myself had noticed), as if, for him, the veil was wearing very thin. Yet there he sat, erect in his big arm-chair, full of life and interest in other people. I thought he might be getting tired, and rose to go. He, rather slowly, grasped my hand and held it, saying "Come again". But that was not to be.

\section{F. IAN G. RAWLINS}

